\title{
Edukacja przez sztukę i do sztuki dzieci i młodzieży na podstawie przekazów łódzkich czasopism kulturalnych ostatniej dekady XX w.
}

Spośród przekazów medialnych, które we współczesnym świecie odgrywają coraz większą rolę, także dla naukowców, warto zwrócić baczniejszą uwagę na przekazy mediów regionalnych. Wyróżniają się one własną specyfiką ${ }^{1}$. Badaczom mogą dostarczyć informacji, których próżno szukać w mediach ogólnopolskich czy globalnych. Rozważając przydatność prasy regionalnej i lokalnej jako źródła do badania dziejów oświaty, warto zwrócić uwagę na jej odrębność zarówno w stosunku do prasy ogólnopolskiej, jak i w stosunku do naukowej prasy pedagogicznej, niezależnie od jej zasięgu.

Badaczowi dziejów wychowania analizującemu prasę regionalną z punktu widzenia potrzeb warsztatu naukowego rzucają się w oczy pewne niedostatki jej artykułów. Wynikają one m.in. z tego, że ich autorami są najczęściej zawodowi dziennikarze, nie zaś osoby o wykształceniu pedagogicznym, grupa adresatów zaś - liczna i znacznie zróżnicowana. Istnieją jednak także liczne walory tego rodzaju dziennikarstwa.

Analiza prasy regionalnej dla potrzeb badania dziejów oświaty pozwala na dotarcie do informacji o wydarzeniach o mniejszym zasięgu, które w prasie ogólnopolskiej nie zostają uwzględnione. Artykuły są, co prawda, uboższe o szereg

* Dr, Zakład Teorii Wychowania Estetycznego, Katedra Edukacji Artystycznej, Wydział Nauk o Wychowaniu, Uniwersytet Łódzki, 91-408 Łódź, ul. Pomorska 46/48.

${ }^{1} \mathrm{Na}$ odmienność mediów regionalnych i lokalnych zwracają uwagę m.in. Sylwester Dziki i Włodzimierz Chorązki, formułując nawet odmienną typologię funkcji dla tych mediów. S. D z i k i, W. C ho rą z k i, Media lokalne i regionalne, [w:] Dziennikarstwo i świat mediów, red. Z. Bauer, E. Chudziński, Kraków 2000. 
specjalistycznych danych, jednak „w zamian” podają informacje innego rodzaju. Dziennikarze, opisując na przykład imprezy kulturalne czy edukacyjne, przedstawiają zwykle poziom frekwencji, podają wiek uczestników, opisują ich reakcje, a nawet zamieszczają wypowiedzi zawierające wrażenia „na gorąco”. Z punktu widzenia dziennikarza takie informacje mają sprawić, że opisywanym wydarzeniem zainteresuje się jak największe grono czytelników, dla których tekst oparty na naukowych faktach wydawałby się zbyt „suchy” i przez to nie dość ciekawy. Informacje „poboczne” mogą być jednak znaczące także dla badacza, pomagając mu zrekonstruować sytuację, co jest cenne zwłaszcza wtedy, gdy nie ma możliwości bezpośredniego kontaktu z organizatorami czy uczestnikami danego wydarzenia. Czasopisma niespecjalistyczne częściej niż naukowe publikują zdjęcia, które w wielu przypadkach trafnie uzupełniają tekst.

Czasopisma ogólnotematyczne oraz kulturalne, w odróżnianiu od czasopism naukowych, w zagadnieniach pedagogicznych skupiają się na praktyce edukacji i wychowania, znacznie mniej uwagi poświęcając teorii i rozwojowi nauki. Stąd na ich łamach znajdziemy raczej informacje o zmianach w programie nauczania, konkursach i festiwalach czy nowych propozycjach artystycznych dla dzieci i młodzieży, przygotowanych przez muzea, teatry, domy kultury. Sporadycznie zaś publikuje się artykuły o konferencjach i zjazdach naukowych czy naukowych publikacjach, nawet znaczących w danej dziedzinie, wychodząc z założenia, że byłyby one interesujące dla zbyt wąskiego kręgu odbiorców.

Warto też zwrócić uwagę na różnice między prasą codzienną a czasopismami. W dziennikach jedną z dominujących jest funkcja informacyjna ${ }^{2}$, zwykle utożsamiana z upowszechnieniową. Czasopisma natomiast, czyli druki periodyczne ukazujące się nie częściej niż raz w tygodniu ${ }^{3}$, starają się na ogół włączać w tok debaty publicznej i realizować funkcję opiniotwórczą ${ }^{4}$. Dlatego na ich łamach częściej pojawiają się takie gatunki dziennikarskie, jak felieton, wywiad czy recenzja. W czasopismach kulturalnych publikują zwykle osoby o wykształceniu humanistycznym i artystycznym, podczas gdy w dziennikach - niemal wyłącznie zawodowi dziennikarze.

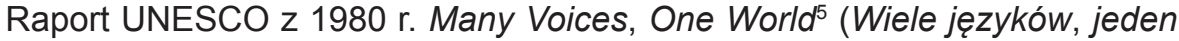
świat), zwany Raportem MacBride'a, zwraca ponadto uwagę na dwie inne funkcje mediów, istotne z punktu widzenia pedagoga. Są to: edukacja, polegająca na „przekazywaniu wiedzy, aby osiągnąć intelektualny rozwój, kształtowanie charakteru i zdobywanie umiejętności oraz zdolności na wszystkich etapach życia", oraz powiązane z edukacją upowszechnianie kultury, czyli „rozpowszechnianie produktów kulturowych i artystycznych, by chronić spuściznę przeszłości; rozwój kultury poprzez rozszerzanie indywidualnych horyzontów, pobudzanie wyobraźni oraz stymulowanie estetycznych potrzeb i kreatywności".

Funkcje te są istotne zwłaszcza dla działań z zakresu edukacji przez sztukę i do sztuki. Przeglądając prasę, można zatem z jednej strony pozyskać informacje

\footnotetext{
${ }^{2}$ W. P is a r e k, Słownik terminologii medialnej, Kraków 2006, s. 62-63.

3 Tamże, s. 25.

4 Tamże.

${ }^{5}$ www.unesco.org [dostęp: 14.08.2006].
} 
na temat edukacji w danym okresie i na danym terenie, a z drugiej - śledzić, w jaki sposób dany tytuł prasowy mógł działać stymulująco na odbiorców.

Sięgającą Platona tezę, że sztuka powinna być podstawą wychowania, podjął i rozwinął Herbert Read, a w Polsce spopularyzowała ją m.in. Irena Wojnar. Działania z tego zakresu powinny mieć miejsce zarówno w szkolnictwie, jak i w placówkach edukacji równoległej, a także w rodzinie. Przeglądając prasę regionalną, trzeba liczyć się z tym, że zamieszczone są tam głównie informacje dotyczące instytucji kulturalnych, nie zaś szkół czy przedszkoli, a jednorazowe akcje artystyczno-edukacyjne cieszą się większym zainteresowaniem dziennikarzy od regularnych działań oświatowych.

Z uwagi na tematykę tego artykułu - zagadnienia z zakresu edukacji przez sztukę i do sztuki dzieci i młodzieży - najbardziej wartościowym źródłem wiedzy okazały się czasopisma o tematyce kulturalnej. Spośród ukazujących się w Łodzi w ostatniej dekadzie XX w. regionalnych czasopism kulturalnych wybrano trzy: „Kalejdoskop”, „Tygiel Kultury” oraz „Kronikę Miasta Łodzi”.

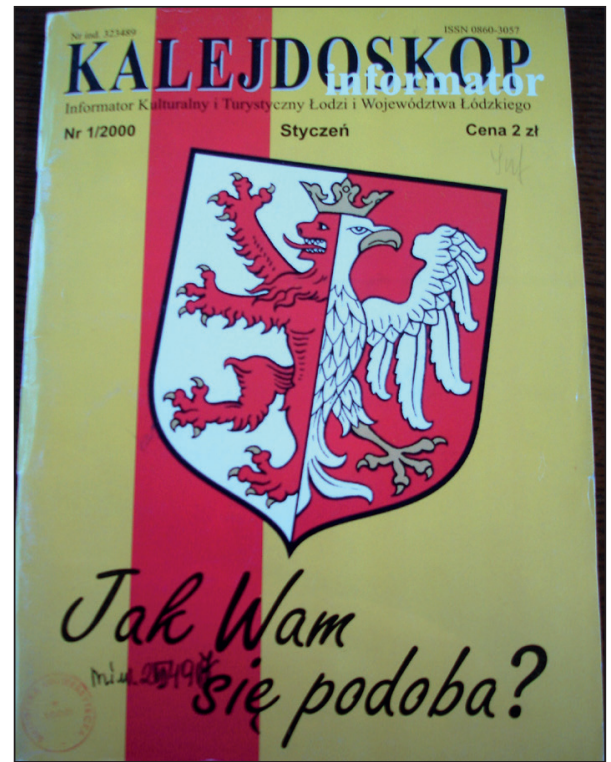

Fot. 1. „Kalejdoskop” 2000, nr 1

„Kalejdoskop” to miesięcznik wydawany do dziś przez Łódzki Dom Kultury, w niewielkim nakładzie (ok. 2700 egzemplarzy). Obecnie nosi podtytuł „magazyn kulturalny Łodzi i województwa łódzkiego", do roku 1992 wychodził jako „informator kulturalny Łodzi i województwa łódzkiego", a następnie jako „Łódzki Informator Kulturalny, Sportowy i Turystyczny”.

Zamieszczane na jego łamach szczegółowe comiesięczne kalendarium imprez kulturalnych Łodzi i okolic pozwala porównać ówczesną i obecną ofertę kulturalną dla dzieci i młodzieży. Wbrew temu, co może wydawać się z dzisiejszej perspektywy, na początku lat 90 . oferta nie tylko koncertów i przedstawień, ale także różnego rodzaju zajęć warsztatowych nie była uboga. Warsztaty muzealne dla dzieci w Muzeum Sztuki prowadzone były wówczas już od wielu lat, także w formule z udziałem rodziców, z myślą o „umożliwieniu im [dzieciom] żywego, emocjonalnego kontaktu ze sztuką współczesną"”. Ponadto w Łodzi odbywały się m.in.: coroczny Konkurs Wiedzy o Sztuce dla uczniów szkół podstawowych, lekcje muzealne i wykłady z historii sztuki dla młodzieży, Olimpiada Artystyczna dla Licealistów, projekcje dla młodzieży szkół ponadpodstawowych w ramach edukacji filmowej w Łódzkim Domu Kultury czy Dziecięcy Klub Filmowy w Dzielnicowym

${ }^{6}$ KJ, Edukacja w Muzeum Sztuki, „Kalejdoskop” [dalej: K] 1993, nr 4, s. 40. 
Domu Kultury „Lutnia” - to tylko niektóre przykłady. Artykuły w omawianym miesięczniku pozwalają także zebrać sporo informacji o aktywności wybranych grup dzieci i młodzieży: ich uczęszczaniu na zajęcia w domach kultury, udziale i nagrodach w konkursach artystycznych itp.

„Na brak imprez dla dzieci narzekać w Łodzi nie można” - pisze wyraźnie w 1993 r. Agnieszka Smuga ${ }^{7}$, pierwsze zdanie swego artykułu popierając licznymi przykładami: regularna działalność dwóch dziecięcych teatrów lalkowych, spektakle dla najmłodszych $w$ teatrach dramatycznych, imprezy plenerowe. W tych latach w Łodzi nie brakowało też oferty przygotowanej dla młodzieży - odbiorcy trudniejszego i bardziej wymagającego niż dzieci. Przekonujemy się więc, że ambitne i nowatorskie inicjatywy edukacyjne w zakresie kultury nie są domeną tylko ostatnich lat. „Kalejdoskop” relacjonował m.in. początki działalności łódzkiego oddziału Młodzieżowej Akademii Filmowej (MAF) ca 1992 r. i sięgał do bogatych tradycji edukacyjnych miasta w tej dziedzinie (m.in. postulaty prof. Lewickiego dotyczące konieczności objęcia edukacją filmową dzieci i młodzieży, kurs na prelegentów dla studentów kulturoznawstwa i pracowników domów kultury zorganizowany w latach 80 .). W roku szkolnym 1991/1992 w zajęciach MAF w całej Polsce - nie tylko starannie przygotowanych pod względem repertuarowym projekcjach, ale także dyskusjach, prelekcjach, spotkaniach z artystami, konkursach - wzięło udział ok. 10 tys. osób, w następnym - już trzy razy tyle. Obecnie MAF nadal działa w niektórych miastach Polski, $w$ Łodzi jej siedzibą jest kino Charlie?.

Ciekawe okazują się zamieszczane w „Kalejdoskopie” wypowiedzi działaczy kultury i pedagogów, przekazujące informacje o procesie edukacji przez sztukę ogółu uczniów szkół podstawowych i średnich. Często opinie te różnią się od siebie znacząco. Piotr Grobliński ${ }^{10}$, poeta i polonista w liceum, współtwórca ówczesnej podstawy programowej, uważa, że najważniejsze jest proponowanie młodzieży „poszerzonego programu kulturalnego: literatura współczesna przez całe liceum, nie tylko w ostatniej klasie, dużo pisania, więcej elementów muzyki, malarstwa, teatru i filmu”. U młodzieży nie dostrzega, co prawda, „specjalnej euforii”, obserwuje, że obecnie ludzie „słabiej potrafią mówić, pisać listy, wolą filmy od książek", sądzi jednak, że w każdym człowieku istnieje potrzeba ekspresji artystycznej i „zawsze jakoś się będzie ona przejawiać”. Bardziej pesymistyczna jest zajmująca się edukacją filmową Jolanta Kowalczyk-Śliwerska ${ }^{11}$. Kulturę filmową młodzieży ocenia bardzo nisko: „uczniowie oglądają najchętniej błahe seriale, ich ulubione gatunki to także film sensacyjny, horror". Przypisuje to w dużym stopniu złej edukacji - by temu zaradzić, należy wprowadzić do szkół lekcje autorskie

\footnotetext{
${ }^{7}$ A. S m u ga, Z tatusiem w Pałacu, K 1993, nr 7-8, s. 34.

${ }^{8}$ K. S p y c h a j, Jeszcze jedna Akademia w Łodzi - rozmowa z Hanną Czarnecką, K 1993, nr 9 , s. $40-42$.

${ }^{9} \mathrm{http}: / / \mathrm{www} . c h a r l i e . p l / i n d e x . p h p ? \mathrm{i}=\mathrm{k} 19$ [dostęp: 15.10.2011].

${ }_{10}$ M. Gło wa cki, Poezja, edukacja, kultura - rozmowa z Piotrem Groblińskim, K 1993, nr 3, s. 20-22.

11 J. Ja n y st, O edukacji filmowej optymistycznie - rozmowa z Jolantą Kowalczyk-Śliwerską, K 1993, nr 3, s. 24.
} 
z filmem, co powoli się już dzieje, także w ramach klas autorskich o profilu filmoznawczym.

Aktywny kontakt ze sztuką kształtuje wrażliwą i pełną pasji osobowość; potwierdza to artykuł na temat młodzieżowego teatru „Pod Lupą”, działającego przy Łódzkim Domu Kultury ${ }^{12}$. Rozmowa z jego aktorami - w większości uczniami szkół średnich - udowadnia, że działalność w teatrze pogłębia samoświadomość i wrażliwość, rozwija pracowitość. Jedna z młodych aktorek mówi: „Nareszcie zrozumiałam, że aby zagrać cokolwiek uczciwie przed publicznością, muszę przestać grać w życiu sama przed sobą... Chyba już na zawsze zostanie we mnie skojarzenie teatru z szukaniem, z prawdą, z ciężką pracą, dochodzeniem, z mówieniem w prosty sposób o tym, co najważniejsze"13. O motywach podjęcia swojej przygody ze sztuką mówią też członkowie młodzieżowego Zespołu Piosenki i Tańca „Pędziwiatry”, który w 1999 r. wystawił napisany specjalnie dla niego musical Flakonik Apolonii. Ich wypowiedzi świadczą o tym, w jak znacznym stopniu sztuka ubogaca ich życie, a nawet, być może, chroni przed niebezpiecznymi sposobami spędzania wolnego czasu: „To jedyny sposób [...] zużytkowania całej, drzemiącej w nas energii. Życie bez tańca nie miałoby sensu”; „Na osiedlu przez długi czas nie działo się absolutnie nic. Więc na wieść o formującej się grupie tanecznej postanowiliśmy spróbować naszych sił".

W 1991 r. „Kalejdoskop” włączył się w dyskusję na temat: „czy w Łodzi potrzebne są domy kultury?"14, polemizując z opiniami, jakoby aspiracje kulturalne łodzian mogły zaspokoić telewizja i wideo, a „wymyślone” dawno temu domy kultury to już przeżytek. Przemysław Hachorkiewicz, instruktor jednego z nich, podkreśla, że takie placówki są wciąż potrzebne: „W ciągu tygodnia zgłasza się do nas 5-8 zespołów, które chcą grać. Nie stać ich na własną aparaturę i salę. Potrzebują opieki merytorycznej"15. Zwraca jednak uwagę, że młodzież coraz częściej oczekuje szybkiego sukcesu bez nakładów pracy. Za tę sytuację obwinia szkolnictwo: „Wśród młodzieży dominuje praktycyzm, stąd boom na szkoły zawodowe. Wolą robić pieniądze, kultura ich nie interesuje. Wynika to z nieodpowiedniej edukacji, gdy w przedszkolach i szkołach uczą ludzie przypadkowi, bez ambicji artystycznych". Zwraca uwagę, że w domu kultury powinni pracować ludzie „nieprzeciętni, lepsi od innych, wyselekcjonowani”, dla których jest to „praca pedagogiczna, ale i twórcza".

Rozmówcy „Kalejdoskopu” w latach 90. narzekali na to samo, co jest bolączką pedagogów i twórców kultury obecnie - 15, 20 lat później: że „ludzie, którzy w przyszłości będą fachowcami w dziedzinie kultury, nie chcą uczestniczyć w zajęciach [kulturalnych]"16. By poprawić tę sytuację, proponowano nowe formy zajęć mających przyciągnąć młodzież, np. projekcje wybitnych filmów w języ-

\footnotetext{
12 T. B i e s z c z a d, Jak to się robi „Pod Lupą”, K 1995, nr 5, s. 16-18.

13 Tamże, s. 18

14 P. Ha ch or k i e w i c z, Czy potrzebne nam są domy kultury?, K 1991, nr 4, s. 5-6.

15 Tamże.

${ }^{16}$ K. S p y c haj, Recepta na okres przejściowy - rozmowa z Joanną Malinowską, dyrektorem Oddziału Zarządu Kin Studyjnych w Łodzi, K 1993, nr 5, s. 20-22.
} 
kach oryginalnych z udziałem lektorów, którzy później w danym języku prowadzą dyskusję $z$ widzami ${ }^{17}$.

Lektura wywiadu z dyrektorem Teatru „Pinokio” Grzegorzem Kwiecińskim ${ }^{18}$ i z innymi artystami sprawującymi funkcje kierownicze pozwala nakreślić obraz ludzi, którzy pracowali w kulturze w latach 90., przygotowując ofertę edukacyjną dla dzieci: to ludzie pełni pasji, oprócz pracy etatowej angażujący się także w inne przedsięwzięcia artystyczne, o podejmowanych działaniach i planach mówiący z ogromnym zaangażowaniem. Podkreślają konieczność dbałości o wysoką jakość sztuki dla dzieci i młodzieży, ale też narzekają na trudne warunki realizacji swoich pomysłów, głównie na problemy finansowe. Dostrzec można pewne zagubienie w nowej pokomunistycznej rzeczywistości i realiach gospodarki rynkowej.

W owym czasie wiele placówek edukacyjnych upadało po krótkim okresie działalności. Lektura „Kalejdoskopu” pozwala prześledzić ten proces. O nieistniejącym już dziś Centrum Sztuki Dzieci i Młodzieży w 1993 r. mówili jego założyciele, Urszula i Jan Issaieff ${ }^{19}$. Podkreślali: „my nie uczymy, my staramy się dzieci zachęcać do ekspresji, kształtować ich twórcze postawy..."

Szczególnie interesujące wydają się artykuły-polemiki, ukazujące różne punkty widzenia na tę sama kwestię. Takie publikacje szczególnie zachęcają czytelnika do zajęcia własnego stanowiska, pełnią więc funkcję opiniotwórczą i aktywizującą. Przykładowo, w lutym 1993 r. opublikowano entuzjastyczną relację Ireny Stanisławskiej z bytności z dzieckiem na przedstawieniu Koty w Teatrze Arlekin ${ }^{20}$. „Dawno nie widziałam tak wspaniałego przedstawienia dla dzieci i równocześnie dla dorosłych: dowcipnego, inteligentnego, pełnego odniesień słownych (porzekadła), politycznych i muzycznych [...]" - pisze autorka ${ }^{21}$. Czytelnik otrzymuje, co prawda, informację, że przedstawienie okazało się trudne dla dzieci, jednak dyrektor teatru i reżyser spektaklu Waldemar Wolański wskazuje na przyczynę: „widownia teatralna jest przyzwyczajona do repertuaru, który operuje najprostszymi schematami, typu: czarne-białe. I bardzo ciężko jest przekonać widzów do pewnej inności. [...]". Zwraca uwagę, że wynika to z braku edukacji teatralnej dzieci, które wychowują się na prostych, 10-minutowych Dobranockach, „Natomiast przewaga i urok teatru polega na tym, że nie jest to tylko sprawa fabuły, ale także nastroju, przestrzeni, oddechu, pewnej realności, którą widzimy. I tego trzeba nauczyć. Zresztą, m.in., taka jest funkcja teatru lalek, aby nauczył dzieci odbioru tej formy sztuki. Nie chodzi o to, aby ich przyzwyczaić do określonych kanonów estetycznych, ale o to, aby nauczyły się czytać teatr"22. Z tą opinią trudno się nie zgodzić, jednak zdanie na temat spektaklu Koty można zmienić po lekturze tekstu Agnieszki Smugi23, opublikowanego trzy miesiące później.

17 Tamże.

18 B. R z y m s ka, Oblicza Teatru Lalki - rozmowa z Grzegorzem Kwiecińskim, K 1992, nr 10, s. 20-22; B. J ę d r z e j c z a k, 45 lat minęło... - rozmowa z Jackiem Gwizdałą, dyrektorem „Semafora”, K 1992, nr 11, s. 11-13.

19 J. M o n i a k, Najważniejsze są dzieci, K 1993, nr 12, s. 25-27.

20 I. St a n isła w s k a, Nie tylko o „Kotach”, K 1993, nr 2, s. 19-20.

21 Tamże, s. 19.

22 Tamże, s. 19-20.

${ }^{23}$ A. S m u g a, Teatr dla dzieci, czyli dorośli górą, K 1993, nr 5, s. 12. 


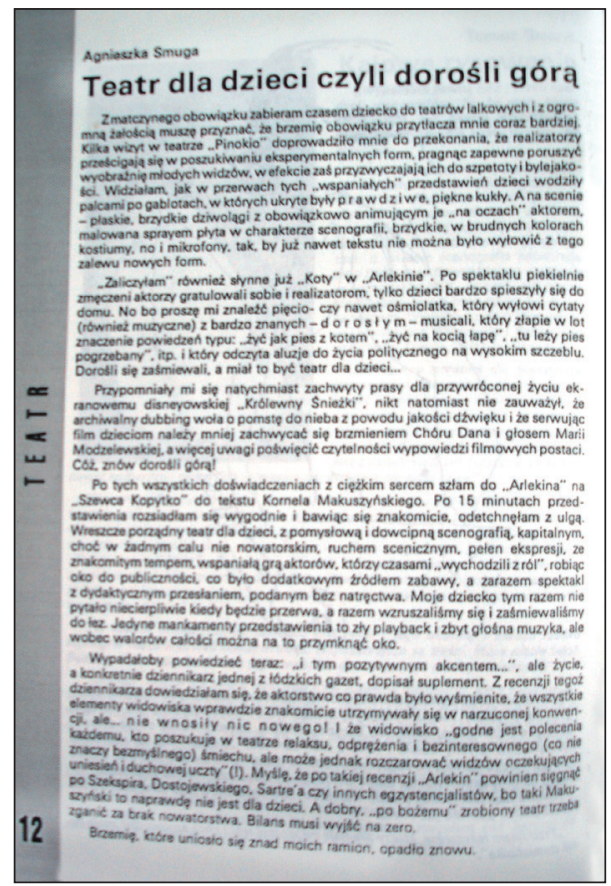

Fot. 2. Artykuł A. Smugi Teatr dla dzieci czyli dorośli górą,

„Kalejdoskop” 1993, nr 5, s. 12
Autorka wyraźnie odmiennie postrzega potencjał tego przedstawienia: „Po spektaklu piekielnie zmęczeni aktorzy gratulowali sobie i realizatorom, tylko dzieci bardzo spieszyły się do domu. No bo proszę mi znaleźć pięcio- czy nawet ośmiolatka, który wyłowi cytaty (również muzyczne) z bardzo znanych - dorosłym - musicali [...] i który odczyta aluzje do życia politycznego na wysokim szczeblu. Dorośli się zaśmiewali, a miał to być teatr dla dzieci..." Zwraca uwagę, że przedstawienia dla dzieci nie muszą być „odkrywcze” ani „pełne uniesień”, ale powinny być przede wszystkim zrozumiałe dla młodych widzów oraz wykonane pomysłowo, dowcipnie i z dbałością o aktorskie rzemiosło.

Edukacja przez sztukę i do sztuki młodzieży, zwłaszcza w jej wymiarze pozaszkolnym, osadzona jest głęboko $w$ realiach życia kulturalnego miasta. Pośrednio zatem z zagadnieniem tym związane są artykuły zawierające rozważania na temat potencjału kulturalnego i artystycznego regionu oraz odzwierciedlające atmosferę artystyczną miasta. Na przestrzeni ostatniego dziesięciolecia XX w. nastąpiły w tym względzie znaczące zmiany. Z lektury „Kalejdoskopów" z początku lat 90. wyziera poczucie niższości łodzian w stosunku do mieszkańców innych miejscowości w Polsce, pogłębiane jeszcze poczuciem zagubienia i pewnej bezradności w nowych, trudniejszych warunkach postkomunistycznej gospodarki rynkowej. Niemal wszyscy dyrektorzy domów kultury czy teatrów skarżą się na problemy finansowe. Autorzy artykułu Genius loci...? Fatum loci... $?^{24}$ z 1991 r., zastanawiając się, ,jaka jest ta - łódzka kultura?” i ,jaka kultura jest Łodzi potrzebna?", ubolewają nad tym, że łodzianom skutecznie wmawia się "gorszość" w stosunku do reszty kraju oraz wskazują na potrzebę budowania poczucia tradycji i odczuwania więzi lokalnej. Zwracają uwagę na to, że przez wiele lat w Łodzi niesłusznie popierano tylko „kulturę «robotniczą»”, popularną, niską, zaniedbując kulturę wysoką. Klimat artykułów publikowanych w "Kalejdoskopie” w 1991 r. jest budowany tak, by podkreślać potencjał kulturalny Łodzi i przekonywać: a jednak się da! Z czasem nastrój wypowiedzi twórców kultury poprawia się: co prawda nadal wyjawiają swoje niepokoje związane $z$ finansami, lecz potrafią być bardziej przedsiębiorczy i zdobyć się na większy optymizm.

${ }^{24}$ [Redakcja], Genius loci...?, Fatum loci...?, K 1991, nr 1, s. 2-5. 
W poznaniu ogólnej atmosfery w Łodzi cenne są zwłaszcza tzw. sondy „Kalejdoskopu", czyli wypowiedzi na określony temat ludzi kultury, artystów, osób na kierowniczych stanowiskach. Już w 1994 r. na pytanie, czy twórca wywodzący się z Łodzi może odnieść sukces ogólnopolski ${ }^{25}$, pojawiają się bardziej optymistyczne odpowiedzi: „Jeśli chodzi o możliwość odniesienia sukcesu przez twórcę, Łódź nie różni się specjalnie od innych miast" (Ewa Pilawska - zastępca dyrektora Teatru Powszechnego); „Po ostatnich doświadczeniach uważam, że jeśli ma się do zaprezentowania coś naprawdę innego, nowego, interesującego - jest to możliwe” (Anna Skórska - dyrektor artystyczny Telimeny); „Oczywiście, że Łódź jest takim samym dobrym miastem do robienia kariery jak każde inne" (Andrzej Barut - dyrektor Radia Łódź); „Dla twórców nie ma złych miast i złych miejsc do robienia kariery" (Mieczysław Gumola - dziennikarz, jeden z pomysłodawców i animatorów Światowego Spotkania Łodzian).

Ostatnie lata XX w. - 1999 i 2000 - przyniosły twórcom kultury i edukatorom kolejne niepokoje, związane z niejasnościami reformy administracyjnej $1999 \mathrm{r}^{26}$ Przejście wielu placówek kultury pod egidę Sejmiku Wojewódzkiego nie szło w parze z zapewnieniem odpowiedniego ich finansowania. W tej sytuacji instytucje takie, jak muzeum, teatr czy filharmonia skupiają się na organizacji choć niewielkiej liczby wydarzeń kulturalnych najbardziej dla siebie typowych, działalność edukacyjna schodzi zaś na dalszy plan. Artyści mówią, że „Łódź jest miastem wycofanym z kultury” (Józef Robakowski), a "dezintegracja środowiska twórczego w Łodzi jest totalna" (Andrzej Wilczkowski pisarz, publicysta); tylko niektórzy uważają, że „Łódź zajmuje godną pozycję co do liczebności środowisk plastyków, muzyków, fotografików, architektów, aktorów, pisarzy itd." (socjolog prof. Bogusław Sułkowski) ${ }^{27}$.

Miesięcznik „Tygiel Kultury”, ukazujący się od 1996 r., to, jak piszą sami redaktorzy, „czasopismo społeczno-kulturalne o szerokim zakresie tematycznym”28. Korzystanie z niego ułatwiają badaczom oddzielne tomy bibliograficzne, obejmujące kilka roczników pisma.

Najbardziej interesujące z punktu widzenia edukacji przez sztukę zakresy tematyczne spośród tych, które zostały uwzględnione w bibliografii, to kultura i oświata. O tym, jak niewiele jest tego typu artykułów, niech świadczy fakt, że w dziale „Oświata” w bibliografii obejmującej pięć roczników znalazły się tylko dwie pozycje. W pewnym stopniu użyteczne mogą być też działy odpowiadające poszczególnym dziedzinom sztuki: Teatr; Kino. Film; Sztuka; Sztuki plastyczne; Muzyka itd. W „Tyglu...” wiele miejsca poświęca się zjawiskom i postaciom kultury powszechnej, nie tylko polskiej, łódzkiej poświęcając nieco mniej uwagi. Co wię-

${ }^{25}$ Sonda „Kalejdoskopu”, K 1994, nr 4, s. 9, 11, 22, 24, 26, 29, 34, 36, 39.

26 Taki pejzaż..., K 1999 nr 1, 24-stronicowa wkładka z wypowiedziami 20 artystów i ludzi kultury; M. Karb owiak, Jak dzielić to, czego nie ma? - wypowiedź przewodniczącej Komisji Kultury Sejmiku województwa łódzkiego Doroty Biskupskiej-Neidowskiej, K 2000, nr 1, s. 3-6.

27 Taki pejzaż...

28 „Tygiel Kultury”, bibliografia 1996-2000, s. 6. Przyszłość czasopisma stanęła pod znakiem zapytania, gdyż w roku 2011 nie otrzymało w ogóle dotacji z Ministerstwa Kultury i Dziedzictwa Narodowego, http://tygiel.free.ngo.pl [dostęp: 12.10.2011]. 

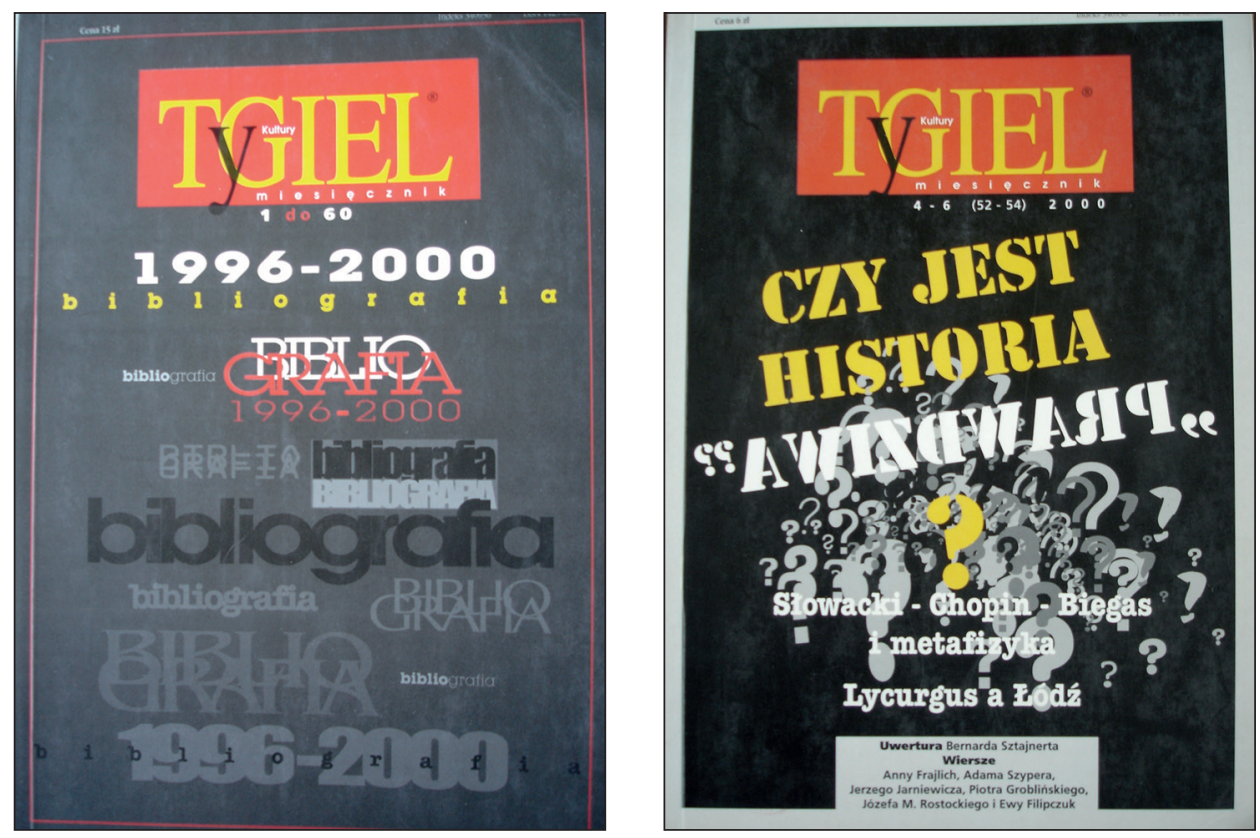

Fot. 3. „Tygiel Kultury”, bibliografia 1996-2000 oraz „Tygiel Kultury” 2000, nr 4-6

cej, podobnie jak w „Kronice Miasta Łodzi”, wiele tekstów dotyczy historii kultury, nie zaś współczesności. Stosunkowo dużo publikuje się wierszy oraz reprodukcji dzieł plastycznych. Poświęca się także uwagę kwestiom wykraczającym poza wąsko rozumianą kulturę, np. zagadnieniom tolerancji wobec osób innej narodowości i wyznania ${ }^{29}$. Zatem „Tygiel...” może być raczej źródłem inspirujących tekstów do wykorzystania w procesie edukacji przez sztukę, niż źródłem dla historyka wychowania.

Pewne informacje dotyczące imprez kulturalnych z udziałem dzieci i młodzieży można znaleźć w dziale „Kronika”, są one jednak bardzo lakoniczne, mogą więc służyć najwyżej jako punkt wyjścia do dalszych poszukiwań. Ewentualne korzyści dla historyka wychowania są więc głównie pośrednie i polegają na bliższym poznaniu pewnego klimatu intelektualnego panującego w Łodzi w określonych latach - pod tym względem najbardziej użyteczne wydają się felietony, prezentujące w swobodnej formie pogląd autora na określone zjawiska kulturalne, nie bez odniesień do cudzych postaw i poglądów. Przykładowo, w felietonie z cyklu Od róż do liter ${ }^{30}$ Lucyna Skompska oddaje się niewesołym rozmyślaniom o tym, jak niedocenieni są w Łodzi twórcy kultury i jak sytuacja zmienia się na ich korzyść, gdy tylko opuszczą rodzinne miasto. Wspomina postacie niemal całkiem w Łodzi zapomniane, choć wybitne, takie jak powieściopisarka Wanda Karczewska, poeci Jan Huszcza i Bernard Sztajnert czy plastyk Antoni Mikołajczyk. Rozważania

29 „Tygiel Kultury” 2000, nr 7-9, artykuły w dziale „Tolerancja / Nietolerancja”, s. 6-60.

30 L. S k o m p s k a, Od róż do liter, „Tygiel Kultury” 2000, nr 4-6, s. 73-74. 


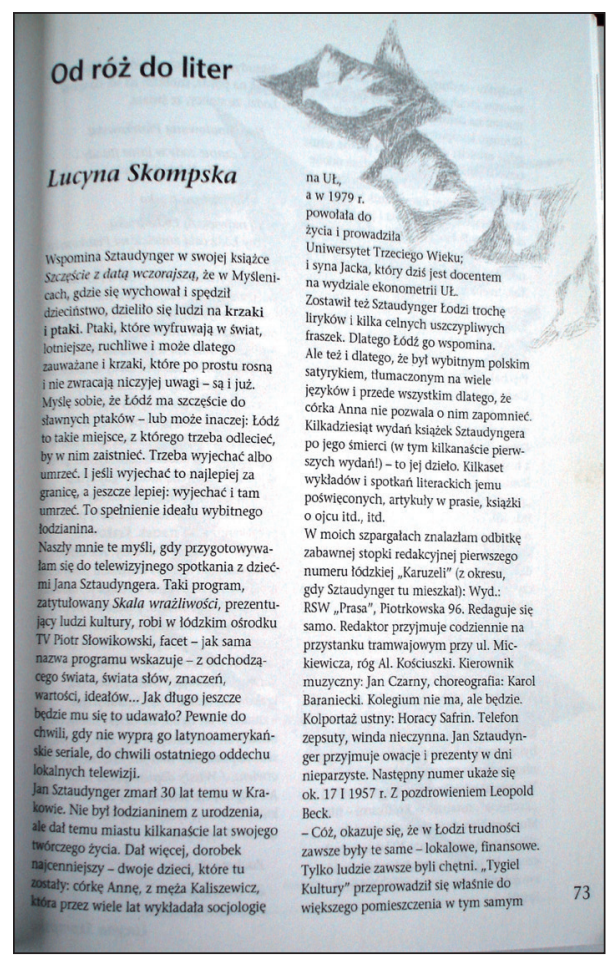

Fot. 4. Felieton L. Skompskiej z cyklu Od róż do liter, „Tygiel Kultury” 2000, nr 4-6, s. 73-74 takie tylko pozornie są $w$ niewielkim stopniu związane z edukacją do sztuki i przez sztukę...

Do nielicznych tekstów poświęconych stricte zagadnieniu edukacji przez sztukę należy artykuł pt. Każdy początek... Doświadczenia pewnej wymiany polsko-niemieckiej ${ }^{31}$ z 2000 r. Dotyczy on dwuletniej uczniowskiej wymiany polsko-niemieckiej między uczniami łódzkich i stuttgarckich szkół ponadpodstawowych, w ramach której odbywały się także wydarzenia kulturalne, takie jak wystawa fotograficzna w Niemczech czy program kulturalny dla uczniów niemieckich, obejmujący zwiedzanie Krakowa, Częstochowy, Wieliczki oraz Oświęcimia. Zasadniczą częścią programu był realizowany plastycznie projekt „Stuttgart i Łódź przełomu wieków". Oprócz podstawowych informacji autor przedstawia nastawienie do projektu biorących w nim udział uczniów, przytacza wypowiedzi konkretnych osób. Młodzież polska

i niemiecka podczas pobytów za granicą poznaje się dobrze, co daje szansę nawiązania trwałych przyjaźni. Młodzi ludzie mieszkają w domach prywatnych, a osobisty kontakt poprzedzony jest znajomością listowną. Jak wskazuje autor, poza problemem finansowym podstawowa trudność rozszerzania tego typu wymiany na inne szkoły polega na tym, że „dużej liczbie polskich szkół zainteresowanych wymianą odpowiada tylko niewielka liczba szkół niemieckich"32. Opisany projekt to piękny przykład połączenia edukacji przez sztukę z edukacją międzykulturową i wychowaniem w duchu tolerancji.

„Kronika Miasta Łodzi”, pismo wydawane przez Urząd Miasta, miało i ma do dziś specyficzny charakter, sprawiający, że nie można uznać go za typowe czasopismo, skupiające się na tym, co dzieje się tu i teraz.

Na początku lat 90. tematyka artykułów wyraźnie wskazywała na charakter pisma jako organu urzędu - pojawiały się np. opisy koncepcji podziału miasta na jednostki samorządowe, z czasem ewoluowało ono w stronę czasopisma historyczno-kulturalnego.

${ }^{31}$ B. Ze y ring e r, Każdy początek... Doświadczenia pewnej wymiany polsko-niemieckiej, „Tygiel Kultury" 2000, nr 1-3, s. 195-198.

${ }^{32}$ Tamże, s. 195. 

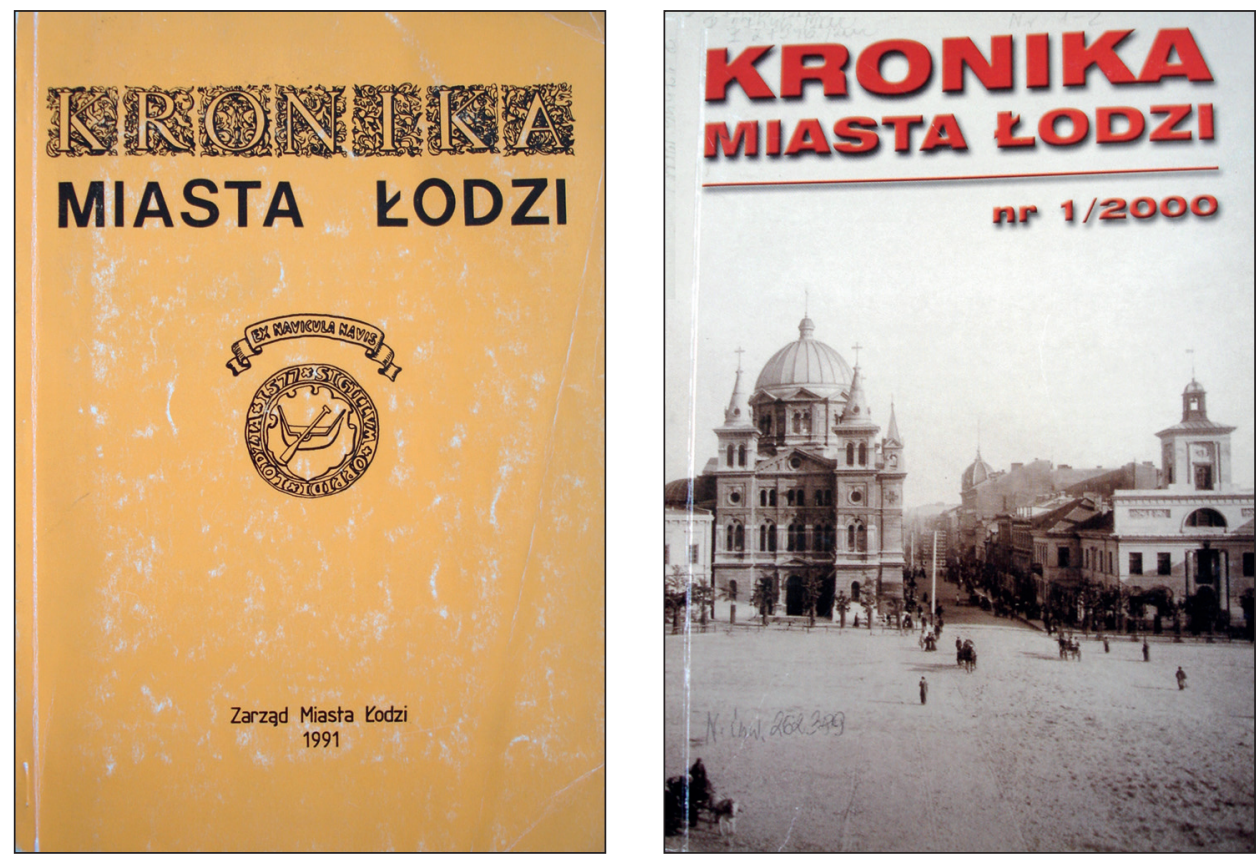

Fot. 5. „Kronika Miasta Łodzi” 1991, nr 1 oraz „Kronika Miasta Łodzi” 2000, nr 1

W „Kronice...” dominują artykuły o charakterze historycznym, dokumentujące przeszłość miasta. Niektóre z nich poświęcone są choć częściowo edukacji artystycznej. Wzmianki na ten temat pojawiają się też w artykułach o innej tematyce, np. dotyczących Łodzi filmowej czy przedstawiających sylwetki zasłużonych łodzian.

Artykułów w piśmie jest stosunkowo niewiele, biorąc pod uwagę objętość - kilkanaście tytułów na ponad 200 stronach - są one jednak obszerne i wyczerpujące. Informacje mają głównie charakter historyczny - obfitują w daty, liczby, zestawienia danych; mniej jest spostrzeżeń typu socjologicznego, natomiast w ogóle nie pojawiają się takie elementy wypowiedzi dziennikarskiej, jak wywiady czy cytaty wypowiedzi. Autorami tekstów są najczęściej historycy.

Interesująca okazuje się konfrontacja informacji o edukacji kulturalnej sprzed lat 20 czy 10 ze współczesnym obrazem miasta i jego życia kulturalnego. W artykule Eweliny Nurczyńskiej-Fidelskiej Łódź filmowa. Szkic do portretu ${ }^{33}$, który poświęcony jest „panoramie różnych form istnienia i manifestacji kultury filmowej w Łodzi”, zawarte są m.in. informacje o Dyskusyjnych Klubach Filmowych, działających przy małych kinach i środowiskowych domach kultury.

Często gromadziła się w nich młodzież studencka. Pierwszy taki klub powstał w Łodzi w 1957 r. Autorka zajmuje się także dziejami edukacji przyszłych

${ }^{33}$ E. Nurczyńska-Fidelska, Łódź filmowa. Szkic do portretu, „Kronika Miasta Łodzi” 2000 , nr 1, s. 9-30. 


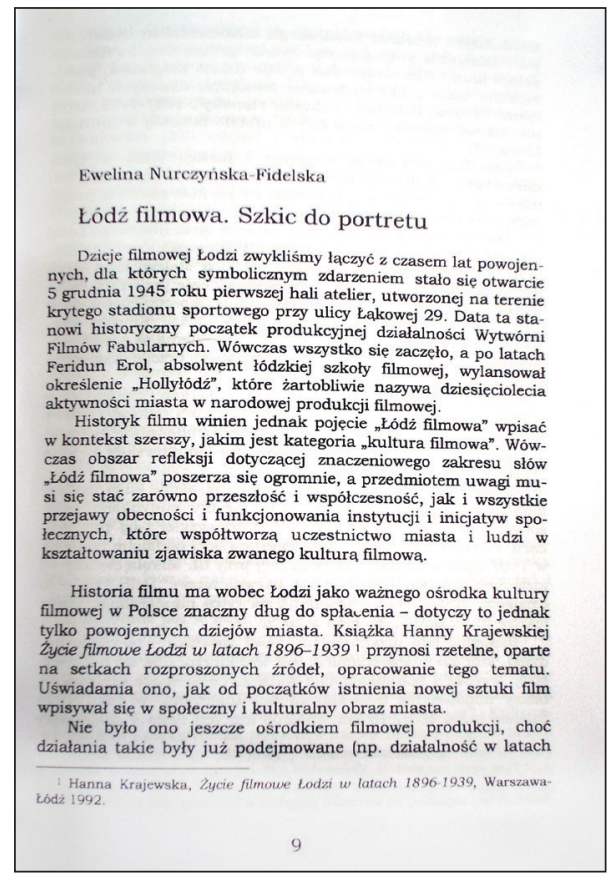

Fot. 6. Artykuł E. Nurczyńskiej-Fidelskiej Łódź filmowa. Szkic do portretu, „Kronika Miasta Łodzi” 2000, nr 1, s. 9-30 filmowców, i to nie tylko na poziomie akademickim. Wspomina o prof. Bolesławie Lewickim, wielkim propagatorze kształtowania kultury filmowej wśród dzieci i młodzieży, a także nauczycieli. Podkreśla, że to $w$ Łodzi na przełomie lat 60. i 70. powstały pierwsze w Polsce kina szkolne. Przypomina o Centralnym Gabinecie Edukacji Filmowej Dzieci i Młodzieży - w Pałacu Młodzieży działa on do dziś. Z nostalgią pisze o „złotych latach" Studia Małych Form Filmowych "Semafor”, które za filmy dla dzieci zebrało wiele nagród krajowych i zagranicznych. Zwraca uwagę na wieloletnią działalność Wytwórni Filmów Oświatowych (powstała w 1946 r., obecnie pracuje pod nazwą: Wytwórnia Filmów Oświatowych i Programów Edukacyjnych). Największe twórcze osiągnięcia WFO związane były z filmami przyrodniczymi, biologiczno-medycznymi, etnograficznymi i z filmami o sztuce.

W artykule Z dziejów szkolnictwa $w \nvdash o d z i^{34}$ niewiele miejsca znalazło się dla edukacji artystycznej. Została tu potraktowana - to niestety nie wyjątek - jako zagadnienie osobne, w niewielkim stopniu powiązane z tokiem edukacji ogólnej. Dowiadujemy się jedynie, że w 1945 r. w pałacu Karola Poznańskiego przy ul. Gdańskiej 32 powstało Państwowe Konserwatorium Muzyczne, w którym rektorem został Kazimierz Wiłkomirski. W tym samym roku pięć miesięcy później działalność zainaugurowała Wyższa Szkoła Sztuk Plastycznych. Po wojnie, ze względu na zniszczenia wojenne w stolicy, Łódź została wybrana na siedzibę Szkoły Tańca Artystycznego i Baletu Klasycznego oraz Szkoły Przemysłu Artystycznego. Od 1948 r. działa w Łodzi Wyższa Szkoła Filmowa.

W artykule o Towarzystwie Przyjaciół Dzieci ${ }^{35}$ natrafić można na nieliczne wzmianki o zajęciach artystycznych proponowanych podopiecznym w latach międzywojennych przez ognisko Robotniczego Wydziału Wychowania Dziecka i Opieki nad nim. Po wojnie zaś dzięki działalności RTPD edukację przez sztukę prowadzono m.in. w świetlicach pozaszkolnych, organizując np. teatr kukiełkowy.

Lektura wybranych czasopism pozostawia wrażenie, że w ostatniej dekadzie XX w. w Łodzi miało miejsce stosunkowo dużo ciekawych i różnorodnych inicja-

${ }^{34}$ L. W W o d k o w s k i, Z dziejów szkolnictwa w Łodzi, „Kronika Miasta Łodzi” 2000, nr 2, s. 55-71.

35 T. P o d w y s o c k i, Z historii Towarzystwa Przyjaciół Dzieci, „Kronika Miasta Łodzi” 2000, nr 2, S. 81-92. 
tyw przybliżających różne dziedziny sztuki dzieciom i młodzieży. Aktywność zarówno domów kultury, jak i teatrów czy muzeów była znaczna, a zaangażowanie ich pracowników i dyrekcji - wysokie. Były to jednak głównie działania lokalne, rzadko wpisujące się w tok wydarzeń ogólnopolskich czy tym bardziej globalnych. Ponadto obejmowały one jedynie dość wąską grupę docelową - najczęściej osoby, które i tak interesują się sztuką - podczas gdy w edukacji przez sztukę należy dążyć do tego, by jej zakresem objąć całą populację.

Można ponadto zauważyć, że edukacja przez sztukę jest w pewnym stopniu dziedziną „bezpańską”: nie do końca wpisuje się w sprawy kultury, nie w pełni także znajduje swe miejsce $w$ tematyce edukacji, znajdując się przez to niejako „pomiędzy”, co jej oczywiście nie służy. Edukacja przez sztukę i do sztuki nie jest postrzegana jako niezbywalny element kultury; przykładem może być jedna z sond „Kalejdoskopu”36, gdzie na pytanie: „Więcej sukcesów czy porażek [w łódzkiej kulturze na przełomie lat]?" odpowiadało 19 osób, gł. dziennikarzy związanych z kulturą. Spośród nich tylko jedna - Leszek Bonar z Telewizji Łódź - nawiązała w pewien sposób do edukacji (zwracając uwagę na trudną sytuację lokalową Szkoły Muzycznej im. Jaracza).
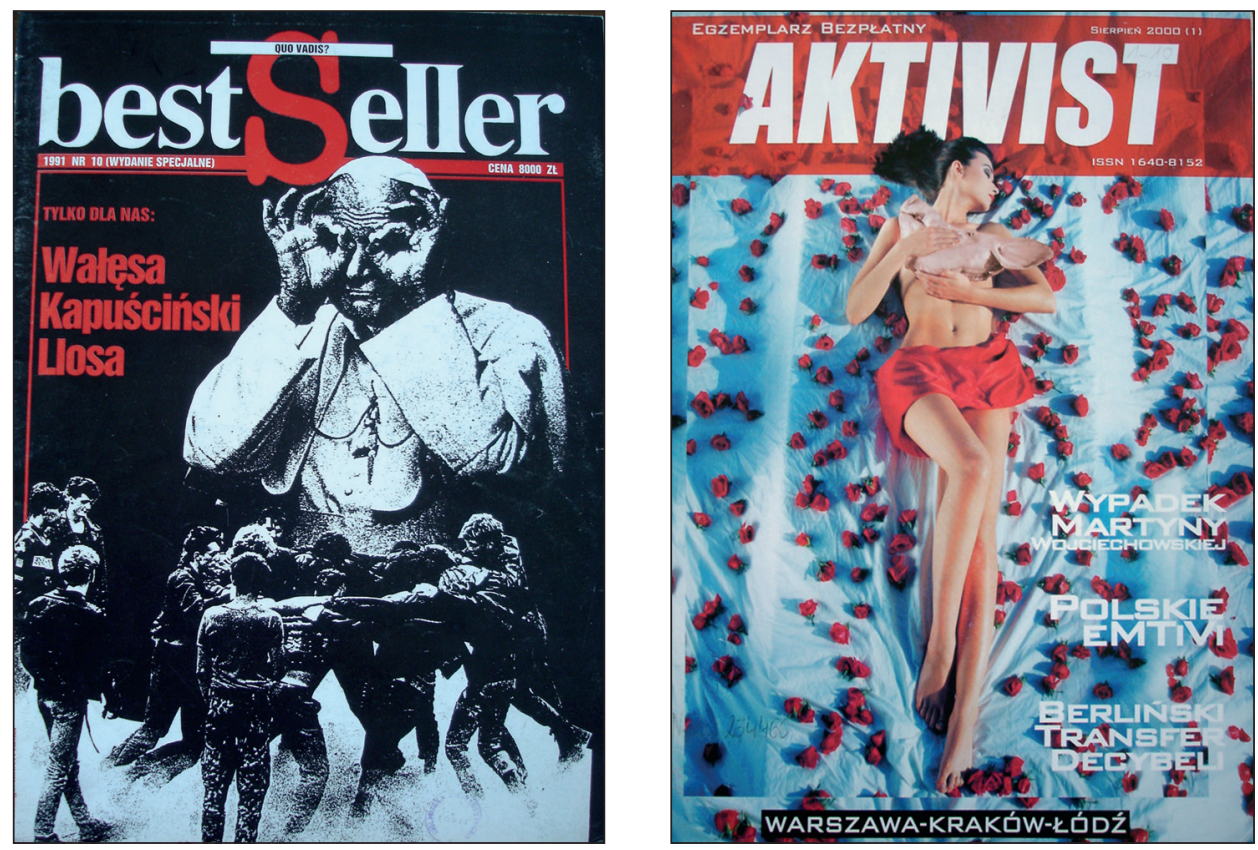

Fot. 7. „Bestseller” 1991, nr 10 oraz „Aktivist” 2000, sierpień

„Kalejdoskop”, „Tygiel Kultury” i „Kronika Miasta Łodzi” to nie jedyne łódzkie czasopisma kulturalne ostatniej dekady XX w. Warto wspomnieć o „Bestsellerze”,

${ }^{36}$ Na przełomie: więcej sukcesów czy porażek?, K 2000, nr 1, s. 2-29. 
który ukazywał się w latach 1990-1992 pod patronatem Państwowej Wyższej Szkoły Filmowej, Telewizyjnej i Teatralnej.

Choć wydawany w Łodzi, poświęcony był jednak ogólnopolskiemu życiu kulturalnemu. Dominowały w nim artykuły publicystyczne, a wywiady z takimi osobistościami życia publicznego, jak Lech Wałęsa czy ks. biskup Józef Michalik oraz publikacje fragmentów nowych książek uznanych autorów, np. Ryszarda Kapuścińskiego, wskazują na wysokie ambicje pisma. W roku $2000 \mathrm{w}$ Łodzi zaczął się ukazywać „Aktivist”, obecny na rynku wydawniczym do dziś. Od początku było to jednak czasopismo w zasadzie ogólnopolskie, posiadające zaledwie kilka lokalnych stron o charakterze typowo informacyjnym, poświęconych wyłącznie zapowiedziom imprez masowych.

Spośród trzech analizowanych tytułów za najbogatsze źródło informacji dla historyka wychowania można uznać „Kalejdoskop”. Ten miesięcznik najpełniej spełnia kryteria definicyjne regionalnego czasopisma kulturalnego ${ }^{37}$. Choć ukazywał się - i nadal ukazuje - w stosunkowo niewielkim nakładzie - dociera do dość precyzyjnie określonej grupy docelowej, co zwiększa jego siłę oddziaływania. Przykład „Kalejdoskopu” i dwóch pozostałych czasopism pokazuje, że prasa o charakterze lokalnym i regionalnym zawiera znaczący potencjał badawczy z punktu widzenia historii wychowania, także edukacji przez sztukę i do sztuki. Między czasopismami a prasą codzienną, jak również między poszczególnymi tytułami, istnieją jednak znaczące różnice, co należy brać pod uwagę przy wyborze analizowanego tytułu prasowego, w zależności od rodzaju poszukiwanych informacji.

37 „Czasopismo kulturalne - publikacja periodyczna (tygodnik, dwutygodnik, miesięcznik, dwumiesięcznik, kwartalnik, rocznik) lub serwis internetowy bądź nieregularnik, poświęcona szeroko pojętym problemom kultury. Zasadniczą część czasopisma kulturalnego wypełniają materiały własne, to znaczy przygotowane przez redakcję i grono współpracowników, oraz prezentacje dokonań twórców”, http://katalog.czasopism.pl/index.php/Czasopismo_kulturalne [dostęp: 15.10.2011]. 